\title{
Perjuangan Diplomasi Indonesia
}

\author{
Dea Ananda \\ Ekis C \\ 90100121084 \\ UIN ALAUDDIN MAKASSAR \\ e-mail:deaananda240103@gmail.com
}

\section{PENDAHULUAN}

Indonesia merdeka pada 17 Agustus 1945. Indonesia berdiri sebagai negara kesatuan yang berbentuk Republik. Bangsa Indonesia berjuang untuk mempertahankan bentuk negara kesatuan dari ancaman Belanda yang ingin kembali menguasai Indonesia. Perjuangan bangsa Indonesia lebih diutamakan pada perjuangan diplomasi. Hal inilah yang secara empirik dan teoritis menarik untuk dikaji. Secara empirik dengan pengkajian secara mendalam akan diketahui nilai juang bangsa Indonesia yang tercermin dalam kemajuan diplomasi. Sedangkan secara teoritik, banyak buku yang menyajikan tentang perjuangan diplomasi mempertahankan NKRI namun masih ada celah-celah yang perlu dijelaskan dalam hal perundingan antara Belanda dan Indonesia hingga membentuk RIS dan kembalinya Indonesia menjadi negara kesatuan. (SUNDARI, 2013)

Salah satu perspektif yang dapat dilakukan dalam membahas kembali Revolusi Indonesia adalah mengungkapkan faktor-faktor yang mempengaruhi urgensi penerapan strategi diplomasi pada Revolusi Kemerdekaan Indonesia. Pengertian diplomasi secara umum dapat dilihat pada ungkapan sebagai berikut:

“diplomasi sangat erat dihu- bungkan dengan hubungan an-tar negara, merupakan seni mengedapankan kepentingan suatu negara melalui negosiasi dengan cara-cara damai apabila mungkin, dalam berhubungan dengan negara lain. Apabila cara-cara damai gagal untuk memperoleh tujuan yang diinginkan, diplomasi mengijin-kan penggunaan ancaman atau kekuatan nyata sebagai cara untuk mencapai tujuan-tujuannya"(Dunia \& Dan, n.d.) 


\section{PEMBAHASAN}

Adapun perjanjian, agresi, dan persetujuam yang terjadi adalah sebagai berikut:

1. Perjanjian Linggajati 11-15/11/1946

Perjanjian Linggarjati merupakan Perjanjian yang muncul setelah Belanda melakukan serangan pasca diumumkan kemerdekaan Indonesia 17 Agustus 1945. Belanda yang tidak mengakui kemerdekaan Indonesia berusaha untuk merebut dan menegakkan wilayah kekuasaan di Indonesia.

Perjanjian Linggarjati membuat wilayah kekuasaan Republik Indonesia semakin sempit yang hanya sebatas Jawa, Sumatera, dan Madura. Untuk mempersempit ruang gerak Republik Indonesia, Belanda membentuk negara boneka. Perjanjian Linggarjati diakhiri dengan perjuangan bangsa Indonesian dalam merebut kemerdekaan secara de facto dan de jure atas seluruh wilayah Republik Indonesia yang dikuasai Belanda.(Susilo \& Wulansari, 2021)

1. Wakil Belanda : Van Mook

2. Wakil Indonesia : Syahrir

Adapun hasil dari perjanjian Linggajati adalah sebagai berikut:

1. Belanda mengakui kekuasaan defacto Indonesia (Jawa, Madura, dan Sumatera) daerah yang di kuasai Belanda dan sekutu akan di kembalikannya

2. Berangsur-angsur di bentuk Negara Indonesia

3. Di bentuk Negara Indonesia Serikat (NIS)

4. Pem. Belanda dan RI akan bentuk Uni Indonesia-Belanda NIS dan Uni

5. Indonesia - Belanda selesai sebelum $1 / 1 / 1949$

6. Pem. RI mengakui akan memulihkan dan lindungi hak milik asing

7. Pem Rid an Belanda sepakat untuk kurangi jumlah tentara kalau ada perselisiha, akan di selesaikan oleh komite arbitrase.

2. Agresi Militer 1 
1. Pada tanggal 21/7/1947 Belanda menyerang Indonesia. Menguasai seluruh pelabuhan di Jawa. Penangkapan orang China di Jawa Barat bangsawan di Sumatera di bunuh.

2. Pada tanggal 29/8/1947 Belanda deklarasikan garis demarkasi Van Mook yang membuat wilayah Indonesia lebih sedikit.

3. Pada tanggal 18/9/1947 Komisi 3 negara di bentuk untuk menyelesaikan masalah.

3. Perjanjian Renville

Adapun hasil dari Perjanjian Renville adalah sebagai berikut:

1. Upaya untuk menyelesaikan masalah di Agresi Militer 1

2. Deklarasi Indonesian di pimpin Amir Syarifuddin

3. Abdul Kadir Wijoyoatmojo perjanjian di adakan di atas kapal Renville

4. Garis demarkasi Van Mook di terima

5. Sepakat untuk menyelesaikan masalah secara damai

6. Kedaulatan Indonesia berada di tangan Belanda selama masa peralihan

4. Agresi Militer 11

1. Sudah ada tanda-tanda Belanda akan langgar Renville

2. Pada tanggal 19/12/1947 Agresi Militer II

3. Ibu kota Jogjakarta berhasil di kuasai

4. Pimpinan Negara di tawan Belanda

5. Syarifuddin Prawiranegara membentuk PDRI dengan ibu kota Bukit Tinggi. Panglima Sudirman melakukan perang Gerilya

5. Persetujuan Roem Royen $14 / 4 / 1949$

Ketika masa awal kemerdekaan, Indonesia dihadapkan dengan agresi militer Belanda ke satu dan dua. Oleh sebab itu, diselenggarakanlah sebuah perundingan untuk mengatasi gejolak itu. Perundingan tersebut dikenal sebagai perundingan Roem-Royen dan hasil perundingannya dikenal menjadi perjanjian Roem-Royen. 
Mohammad Roem adalah salah satu pimpinan organisasi Masyumisaat itu. Perjanjian itu pada akhirnya membawa Indonesia menuju Konferensi Meja Bundar yang secara resmi membuat Belanda mengakui kedaulatan Indonesia. Sehingga, Perjanjian RoemRoyen merupakan peristiwa penting yang menentukan nasib bangsa dan umat Islam Indonesia kala itu. Sehingga, aktivitas perundingan ini juga dapat dikatakan upaya perlawanan terhadap kemungkaran atau kezaliman penjajah yang jelas bertentangan dengan nilai Islam.(Juliantara \& Al-hadid, 2021)

1. Wakil Indonesia : Muh. Roem

2. Wakil Belanda : Van Roem

3. Wakil AS : Merle Cochran

Adapun hasil dari persetujuan ini adalah sebagai berikut:

1. Indonesia akan hentikan perang Gerilya, ikut dalam KMB di Den Haag

2. Belanda mengembalikan RI ke Jogja, bebaskan seluruh politik dan menghentikan gerakan militer, dan menyetujui RI sebagai bagian dari NIS

6. Konferensi Meja Bundar (KMB) Den Haag, 23/8/1949

Hasil persetujuan KMB yang telah disepakati tanggal 2 November 1949, akhirnya menjadi dasar ikatan hubungan diplomatis antara Pemerintah Indonesia dengan Pemerintah Kerajaan Belanda.(Adim, 2014)

Adapun hasil dari Konferensi Meja Bundar adalah sebagai berikut:

1. Belanda mengakui RIS sebagai Negara merdeka dan berdaulat

2. Masalah Irian Barat akan di selesaikan setahun kemudian corak

3. Pemerintahan RIS akan di atur dengan konstitusi oleh para delegasi di KMB

4. Akan di bentuk Uni Indonesia-Belanda yang sifatnya longgar

5. RIS harus bayar hutang Hindia Belanda

6. RIS akan kembalikan hak milik Belanda dan kasih izin untuk perusahaan Belanda.

Pada tanggal 16/12/1949 Soekarno terpilih jadi Presiden RI sementara di isi oleh Mr. 
Dan kemudian pada tanggal 17//8/1945 RIS berakhir, dan terbentukah NKRI. 


\section{DAFTAR PUSTAKA}

Adim, A. (2014). Hubungan Indonesia - Belanda Pasca Konferensi Meja Bundar ( Kmb ) Tahun 1949 - 1962 Hubungan Indonesia - Belanda Pasca Konferensi Meja Bundar ( Kmb ) Tahun $1949-1962$.

Dunia, P., \& Dan, I. I. (n.d.). Konteks Internasional Pasca-.

Juliantara, T., \& Al-Hadid, S. (2021). Penyelesaian Konflik Dalam Organisasi Masyumi Menanggapi Perjanjian Roem-Royen. 02(02), 373-392.

SUNDARI, M. A. (2013). Perjuangan Diplomasi Mempertahankan Negara Kesatuan Republik Indonesia Tahun 1945-1950.

Susilo, A., \& Wulansari, R. (2021). Perjanjian Linggarjati ( Diplomasi dan Perjuangan Bangsa Indonesia Tahun 1946- Linggarjati Agreement ( Indonesian Nation Diplomacy and Struggle 1946-1947 ) Penelitian sejarah di era globalisasi ini sangat penting untuk dilakukan. Sejarah jika tidak diken. Jurnal Pendidikan Sejarah, $10(1), 30-42$. 